\title{
Risk Factor of Postoperative Lumbar Surgical Site Infection: A Literature Review
}

\author{
Tark Hung Chang ${ }^{1}$, Santosh Kumar Sah ${ }^{2}$, Chong Zhang², Xiao Tao Wu ${ }^{2 *}$ \\ ${ }^{1}$ Southeast University School of Medicine, Nanjing, China \\ ${ }^{2}$ Department of Orthopedic Surgery, Zhongda Hospital Southeast University, Nanjing, China \\ Email: *wuxiaotaospine@seu.edu.cn
}

How to cite this paper: Chang, T.H., Sah, S.K., Zhang, C. and Wu, X.T. (2021) Risk Factor of Postoperative Lumbar Surgical Site Infection: A Literature Review. Open Journal of Orthopedics, 11, 97-109. https://doi.org/10.4236/ojo.2021.114010

Received: March 1, 2021

Accepted: April 11, 2021

Published: April 14, 2021

Copyright () 2021 by author(s) and Scientific Research Publishing Inc. This work is licensed under the Creative Commons Attribution International License (CC BY 4.0).

http://creativecommons.org/licenses/by/4.0/

\section{(c) (i) Open Access}

\begin{abstract}
Nowadays there have been various advanced techniques to overcome disparate types of lumbar degenerative diseases. However, post-operation complications such as Surgical Site Infection (SSI) still give the surgeon with a big challenge. This article is going to study the risk factor that causes the lumbar SSI by reviewing all the articles that can be assessed through PubMed, websites of science and other internet data base. Numerous articles have stated different reported prevalence rates of $0.7 \%$ to $16 \%$ for surgical site infection. This article will document the most common and significant risk factors for SSI. At last, we suggest that there should be preoperative patient screening and postoperative internal environment maintenance, this will be the best way to reduce postoperative SSI rate or prevent SSI from happening.
\end{abstract}

\section{Keywords}

Surgical Site Infection (SSI), Post-Operative Lumbar Surgery, Risk Factor, Lumbar Fusion, Review

\section{Introduction}

Surgical Site Infection (SSI) in spine surgery remains a significant etiology that led to morbidity, increased medical cost, and prolonged hospitalization. Recently, because there has been development of prophylactic antibiotics and advances in surgical technique and postoperative care, wound infection continues to compromise patients' outcome after surgery [1]. This kind of infection places the patient at risk for pseudoarthrosis, adverse neurologic sequelae, chronic pain, deformity and even death. Surgical site infection will prolong the hospitalization and increase the burden to the patient no matter what conservative therapy or re-operative therapy is [2]. This article is going to study the risk fac- 
tor that causes the lumbar surgical site infection by reviewing all the articles that can be assessed through PubMed, ZhiWang (China National Knowledge Infrastructure) and other internet data base. The flow diagram of literature analysis is shown in Figure 1, 117 articles were found from the internet data base, 37 articles were excluded without full text access and 80 articles were further extracted for reading. About 50 articles were removed due to not relating to Risk factor or lumbar SSI. Furthermore, 30 articles were fully read, then 18 articles were excluded due to lacking evidence. Finally, 12 articles were fully extracted for the study.

\section{Incidence}

Numerous articles have stated different reported prevalence rate of $0.7 \%$ to $16 \%$ for surgical site infection [3]-[8]. Factor affecting SSI can be classified into patient related risk factor and surgical related one. They are uncontrolled diabetes Mellitus, obesity, BMI, smoking, age, malnutrition, immusupressor user and operation duration, degree of operation, and instrument used in surgery, respectively [9]. Previous studies also showed SSI significantly occurring in posterior spine surgery. However, few factors have been associated consistently with increasing the risk of developed spine SSI. Table 1 shows the risk factor correlated to the lumbar SSI with the infection rate 1.5\% - 10\%, which fulfills the reported prevalence SSI infection rate.

117 articles searches on PubMed, Google Scholar, ZhiWang (China National Knowledge Infrastructure)

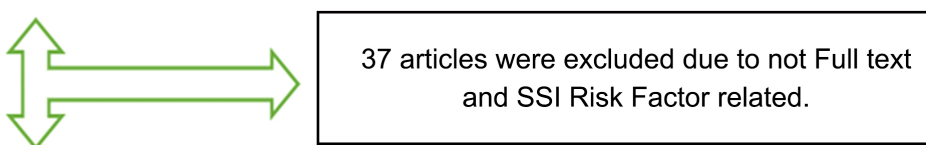

80 Full text articles were extract for reading.

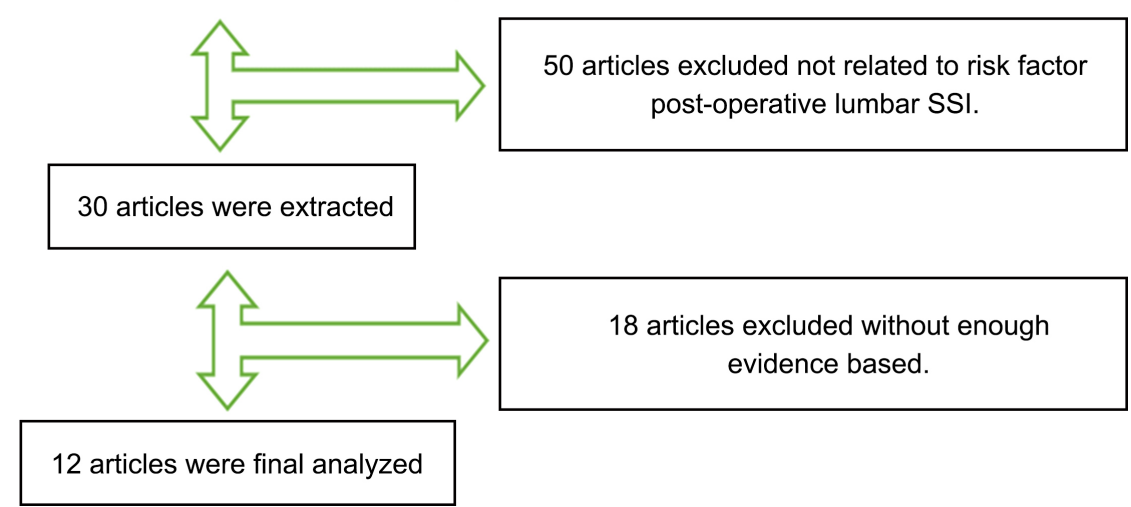

Figure 1. Flow diagram of literature analysis. 
Table 1. Risk factor correlated with SSI.

\begin{tabular}{|c|c|c|c|c|c|}
\hline Author & Design & SSI group & Non-SSI group & Finding risk factors/Result & Infection rate (\%) \\
\hline Mehta et al. & Retrospective Cohort & 24 & 298 & BMI & 8.0 \\
\hline Haleem et al. & Retrospective Case control & 54 & 2309 & Obesity, hypertension & 2.3 \\
\hline Klemencsics et al. & Prospective Cohort & $25 / 12$ & $723 / 307$ & Old ages, BMI & $3.5 / 3.9$ \\
\hline Kobayashi et al. & Retrospective Case Series & 14 & 384 & BMI, mGPS & 3.6 \\
\hline Olsen et al. & Retrospective Case Control & 46 & 2316 & Diabetes & 2.0 \\
\hline Peng et al. & Retrospective Case Control & 37 & 523 & Diabetes, BMI & 7.1 \\
\hline Bohl et al. & Retrospective Case Series & - & - & $\begin{array}{c}\text { Malnutrition, SSI } \\
(\mathrm{n}=43,100 \text { RR: } 2.3 \mathrm{P}=0.01)\end{array}$ & - \\
\hline Sorensen, L. T. & $\begin{array}{l}\text { Review cohort and } \\
\text { randomized control trail. }\end{array}$ & - & - & $\begin{array}{c}\text { Smoking, smoker and non smoker } \\
\text { were compared in } 140 \text { cohort } \\
\mathrm{n}=479,150, \text { SSI }(\mathrm{OR}=1.79 \\
95 \% \mathrm{CI}=1.57-2.24) ; \text { In } 4 \mathrm{RCT} \\
\text { studies smoking cessation reduce } \\
\text { SSI }(\mathrm{OR}=0.4395 \% \mathrm{CI}=0.21-0.85)\end{array}$ & - \\
\hline Kim et al. & Retrospective cohort & - & - & $\begin{array}{l}\text { Surgical duration more than } 5 \text { hours } \\
\text { increase the risk of SSI (Table 2) }\end{array}$ & \\
\hline Rechtine, G et al. & Retrospective Case Series & 12 & 117 & Trauma & 10.0 \\
\hline Ranson et al. & Retrospective Cohort & - & - & $\begin{array}{c}\text { Chronic Steroid user } \\
(\mathrm{N}=849 \mathrm{OR}=8.13 \mathrm{P}=0.001)\end{array}$ & - \\
\hline Mueller et al. & Retrospective Case series & 21 & 1442 & $\begin{array}{l}\text { Minimal invasive surgery (MIS) has } \\
\text { lower rate of SSI compare to open sur- } \\
\text { gery. Total SSI is } 21 \text {, MIS } 5 \\
\text { Open } 16, \mathrm{P}=0.002\end{array}$ & 1.5 \\
\hline
\end{tabular}

Table 2. Correlation of the surgical duration with SSI (Kim et al., 2014).

\begin{tabular}{|c|c|c|c|c|c|c|}
\hline \multirow{2}{*}{ Operative Duration (hr) } & \multicolumn{3}{|c|}{ Superficial SSI } & \multicolumn{3}{|c|}{ Organ/Space SSI } \\
\hline & OR & $95 \% \mathrm{CI}$ & $\mathbf{P}$ & OR & $95 \% \mathrm{CI}$ & $\mathbf{P}$ \\
\hline$<2$ & \multicolumn{3}{|c|}{ Ref } & \multicolumn{3}{|c|}{ Ref } \\
\hline $2-2.99$ & 2.6 & $0.96-7.38$ & 0.061 & 2.11 & $0.22-20.49$ & 0.518 \\
\hline $3-3.99$ & 3.85 & $1.40-10.59$ & $0.009^{*}$ & 1.75 & $0.16-19.53$ & 0.648 \\
\hline $4-4.99$ & 4.39 & $1.50-12.88$ & $0.007^{\star}$ & 6.35 & $0.70-57.89$ & 0.101 \\
\hline$\geq 5$ & 3.97 & $1.38-11.46$ & $0.011^{*}$ & 9.72 & $1.18-80.22$ & $0.035^{*}$ \\
\hline
\end{tabular}

\section{Diagnosis}

Definition of surgical site infection is based on the national health care system, superficial or acute surgical site infection which occurs within 30 days after an operative procedure and involves only skin and subcutaneous tissue of the incision with redness and swelling. Deep or late surgical site infection occurs more 
than 30 days after an operative procedure and involves deep soft tissues of the incision fascial and muscle layers [10].

Early diagnosis of surgical site infection can improve the prognosis. Routine blood test with White blood cell count, Lymphocyte, Heparin-binding protein (HBP), Procalcitonin (PCT), C-reactive protein (CRP), ESR combining with imaging technic Magnetic Resonance Imaging (MRI) can increase the accurate diagnosis. MRI due to its sensitivities, early inflammation can be easily seen on the image with hyperintensity [11] [12]. PCT and CRP have more sensitive and reliable peak than ESR while there is an inflammation [13]. CRP has a shorter period of peak than ESR [14] [15] [16] [17]. Another lab diagnosis tool was Heparin Binding Protein (HBP) also called as azurocidin. Many studies showed that it has the better accurate result of detecting infection compared to others shown above. Wu et al. showed that HBP had the best discriminative capacity to distinguish from sepsis than other systemic inflammations [18]. Linder, A et al. figured out that HBP can be used in detecting early bacterial meningitis [19]. According to the above, we know that HBP can also help in early diagnosis of acute SSI, due to HBP deriving from neutrophile protein, it acts as an inflammation amplifier which causes capillaries leakages when the inflammation takes place [20].

\section{Risk Factors}

\subsection{Patient-Related Factors}

1) Body Mass Index (BMI) is a reliable indicator of body fatness for most people. Many articles showed that BMI and SSI have close relationship, Mehta reported that Obesity (BMI $\geq 30)$ causes SSI $(\mathrm{P}=0.025)$ among 298 patients, which is statistically significant [21]. Meta-analysis of Zhang, L.et al. showed the pool estimate suggested that patients with high BMI values had a higher risk of developing SSI (WMD $1.32 \mathrm{~kg} / \mathrm{m}^{2}, 95 \%$ CI 0.39 - 2.25; P = 0.006) [22]. Combining with previous studies, the correlation with increasing BMI and SSI, when BMI is increased by $5 \mathrm{~kg} / \mathrm{m}^{2}$, the risk of postoperative SSI is accordingly increased by $10 \%$. We can ensure that obese patient has higher incident rate of SSI than non-obese patient, fat layer under the incision sites will lead to late healing due to fat liquefaction, this will be the one of the independent risk factors for SSI [23] [24] [25] [26]. Therefore, patient selection will be a key for elective interventions, and appropriate infrastructure aids in the ultimate outcomes for both elective and nonelective surgical treatments to minimize SSI happened [27].

2) Diabetes Mellitus is an independent risk factor of SSI. Olsen found that either preoperative blood glucose $>125 \mathrm{mg} / \mathrm{dL}$ or postoperative blood glucose $>200$ $\mathrm{mg} / \mathrm{dL}$ are in-dependent risk factors for SSI [odds ratio $3.5(\mathrm{P}=0.004)$ [28]. Hwang, J. U. team discovered that hblc level more than $6.9 \%$ would increase the risk of getting SSI [29]. Peng, W. concluded that during 6 years of retrospective study of 523 Diabetes Mellitus patient who went for lumbar surgery, $7.1 \%$ got SSI, superficial infection accounted for $4.2 \%$ and deep infection made up $2.9 \%$ 
[30]. So preoperative blood glucose level, hblc level control is strictly required for prevention SSI.

3) Elderly patients. Many scholars have confirmed that older patients are a crucial risk factor for postoperative incision infection. Studies have shown that age older than 60 is a risk factor for SSI after spinal surgery. The reason why elderly patients are prone to incision infection is considered to be related to the relative decline of surgical tolerance and tissue repair ability in this group of people. A study by Kanafani et al. found that among patients undergoing spinal surgery, the average age of postoperative incision infection was 59 years of age, the mean age with no onset infected patients was 47 years old. This also demonstrates that advanced age is an important risk factor for postoperative incision infection after spinal surgery [31].

4) Smoking can be confirmed as a risk factor for surgical site infection in any types of surgery. Sorensen, L. T. conducted a systemic review and found that smoker had a higher risk to get healing complication after surgery than non-smoker and also smoking cessation intervention could reduce surgical site infection [32]. Pei, H. and their teams conducted case-control studies, finding that for former smoker cessation smoking 6 - 8 weeks before surgery the complication rate had significantly reduced in intervention group compared to control [33]. In this situation, preoperative management for smokers to stop cigarette will be an alternative way to reduce risk of SSI.

\subsection{Surgical-Related Risk Factors}

1) Operation duration. Kim et al. in a multicenter retrospective cohort study showed that increasing the duration of operation time was associated widely with increasing the risk of getting infection and other complications [34]. Meredith reviewed a consecutive series of 3218 patients concluded that incidence rate of getting SSI was $2.6 \%$ with the risk factor longer the duration of surgery [35]. It is believed that minimizing the surgery duration and strictly obeying the operation guideline will bring lower infection rate to the patient. In addition, antibiotic medication should be given during operation and post-surgery if the operation time exceeds more than 3 hours and extends for another 2 days after surgery can significantly minimize the risk of getting SSI from $7 \%$ to $3.6 \%$ stated in Meredith's review.

2) Type of surgery is a procedure or a method that is used to treat or remove the pathology from the lumbar site. Recently, there have been many types of minimal invasive method to overcome degenerative lumbar illness, such as MIS-TLIF, Endo-LIF, UBE, LLIF and so on [36] for open procedures such as TLIF, PLIF. As we know that minimal invasive technique has the lower outcome of SSI compared to routine technique. That might be due to less blood loss during the operation, less surgical area contacted with the open atmosphere [37]. This brings the patient with better prognosis and shorthorns the hospital stays [38]. 
3) Level of fusion and blood loss prior to the surgery. Previous studies had already noted that blood loss was correlated with level of intervertebral body fusion, as the incision getting larger the blood will loss more during the operation. This leads to risk of SSI happen. Hollern et al. presented that number level of spinal fused was an independent predictor in patient with postoperative surgical site infection [39]. Other than that, epidural tear is also one of the risk factors to get SSI involved. CSF leakage slows down the wound healing and keeps the surgical area exudate, this provides a condition for micro-bacteria accumulation, thus increases the risk of SSI [40] [41].

\subsection{Other Relative Factors}

1) Malnutrition: Many researchers found that pre-operative and post-operative malnutrition or with low serum albumin patient had higher chance to get involve in SSI. Yamamoto et al. carried out multicenter retrospective studies and showed that malnutrition was an independent risk factor for infection and other complications and increased the length of hospital stay [42]. Malnutrition indicate serum albumin concentration level lower than $3.5 \mathrm{~g} / \mathrm{dL}$. Malnutrition is a potentially modifiable risk factor that may contribute to complications following spinal surgery [43]. In retrospective study of Phan, $\mathrm{K}$ et al. also concluded that a poor preoperative nutrition status had been suggested to be a risk factor for postoperative complications in adults undergoing surgery [44]. Therefore, surgeon was suggested to do preoperative nutrient screening for all the patients who were undergoing elective surgery.

2) Traumatic spine injury or neoplasm population: In numerous articles well documented traumatic spine injury population the SSI rate is significantly higher, especially those with neurologic injury. Rechtine et al. conducted case series studies and concluded that trauma patient with instrument lumbar fixation after surgery had a higher risk of SSI compared to those with elective lumbar surgery, population with complete neuro defy had greater risk [45]. As we know that trauma state or injury state or even tumor patient, body metabolism rate will increase, this will lead to increase minor element consumption such as amino acid and other factors, therefore results in nutrient deficiency. As we know malnutrition is an independent risk factor for SSI. On the other hand, trauma might cause open injury, this increases the chance for pathogen deposited in the body.

3) Prolong bed rest after surgery: From our clinical experience, it is known that patients with long term on bed will always face the wound healing problem. Firstly, long time keeping the same position on bed will cause ischemia around surgical wound due to poor blood perfusion. Secondly, patients living on bed face problem with incision site easily contaminated with urine and feces. Therefore, this might be a risk factor for SSI especial for elderly people with commodities. Recently, many scholars have conducted Enhance Recovering After Surgery (ERAS) studies, significantly showing that the result decreases in the length of hospital stay and related complication. A retrospective study of d'Astorg et al. 
showed no significant difference between BMI, smokers, old ages, DM patients in ERAS program [46]. So, patients are encouraged for earlier ambulation.

4) Long term steroid user: A retrospective analysis result of Singla et al. showed that chronic intake of steroid was associated with significantly increased risk of 1-year mortality and considerably increased risk of SSI at 90 days [47]. Another scholar-Ranson, W. A. et al. from his retrospective cohort study showed that chronic steroid usage would bring severe postoperative site effect, most significantly increased twice of the risk of surgical site complication rate [48].

\section{Prevention and Treatment}

As the infection is firstly discovered, we should start or extend anti-infectious therapy at the first point. Tsubouchi, $\mathrm{N}$ et al. from his review studies showed that the delay in administering effective antibiotic was an independent risk factor for implant removal in posterior spine surgery [49]. Following with that if the surgical site got worse or from MRI could found inflammation exudate formed, re-operation for debridement had to be carried out to eliminate or stop infection widespread. Some articles showed that continuous drainage for the wound or vacuum suction was the best technic for SSI treatment [50] [51] [52]. Many researchers stated that debridement with a course of anti-infection therapy was a standard care for SSI, the prognosis was well-defined [53]. Recently minimum invasive debridement technic also has been introduced by Yang, S. C.in his protocol percutaneous endoscopic debridement technic, which has shown the effectiveness with successful rate of $65 \%$ with low complication compared to open debridement [54]. This method could be an alternative way for certain deep infection patients, it is a minimum invasive surgery compared to traditional way and elderly patient can be tolerant for second operation. On the other hand, some patients suspected with high risk of SSI, local use of vancomycin before closure of the wound will have a better outcome after surgery [55]. From the retrospective study of Tomov, M. et al., it was shown that intraoperation used of local vancomycin and betadine irrigation has significantly reduced by $50 \%$ of the risk of SSI after lumbar fusion surgery [56]. So far, there have been still many controversies about the treatment of postoperative infection of lumbar spine. Kobayashi, $\mathrm{K}$ et al. in multicenter retrospective study concluded that early debridement after SSI diagnosis might have contributed to instrument retention [57]. To this day, early diagnosis with appropriate management of SSI has better prognosis.

\section{Conclusion}

As the risk factor documented in this article is the most common and significant risk factor for SSI, therefore, preoperative screening patient condition and postoperative internal environment maintenance will be the best way to reduce postoperative SSI rate or prevent SSI from happening. Furthermore, for a 
surgeon, it is better to review the patient's condition then carry out with corresponding surgical procedure as this can effectively minimize the rate of SSI. Last but not least, early detection of SSI with the appropriate treatment can relatively reduce the cost and length of hospital stay. Preoperative selection and preparation for elective patient who went for lumbar surgery can significantly reduce the rate of SSI.

\section{Acknowledgements}

We would like to thanks Dr. Chong Zhang from Department of Orthopedics Surgery, Zhongda Hospital, Southeast University, Nanjing, China, for his warm support and valuable guidance.

\section{Conflicts of Interest}

The authors declare no conflicts of interest regarding the publication of this paper.

\section{References}

[1] Bassewitz, H.L., Fischgrund, J.S. and Herkowitz, H.N. (2000) Postoperative Spine Infections. Seminars in Spine Surgery, 12, 203-211.

[2] Veeravagu, A., Patil, C.G., Lad, S.P. and Boakye, M. (2009) Risk Factors for Postoperative Spinal Wound Infections after Spinal Decompression and Fusion Surgeries. Spine, 34, 1869-1872. https://doi.org/10.1097/BRS.0b013e3181adc989

[3] Weinstein, M., McCabe JP, Cammisa FP Jr. (2000) Postoperative Spinal Wound Infection: A Review of 2,391 Consecutive Index Procedures. Journal of Spinal Disorders, 13, 422-426. https://doi.org/10.1097/00002517-200010000-00009

[4] Thalgott, J.S., Cotler, H.B., Sasso, R.C., Larocca, H. and Gardner, V. (1991) Postoperative Infections in Spinal Implants. Classification and Analysis-A Multicenter Study. Spine, 16, 981-984. https://doi.org/10.1097/00007632-199108000-00020

[5] Horan, T.C., Culver, D.H., Gaynes, R.P., Jarvis, W.R. and Reid, C.R. (1993) Nosocomial Infections in Surgical Patients in the United States, January 1986-June 1992. National Nosocomial Infections Surveillance (NNIS) System. Infection Control \& Hospital Epidemiology, 14, 73-80. https://doi.org/10.2307/30147164

[6] Pull ter Gunne, A.F. and Cohen, D.B. (2009) Incidence, Prevalence, and Analysis of Risk Factors for Surgical Site Infection Following Adult Spinal Surgery. Spine, 34, 1422-1428. https://doi.org/10.1097/BRS.0b013e3181a03013

[7] Fang, A., Hu, S.S., Endres, N. and Bradford, D.S. (2005) Risk Factors for Infection after Spinal Surgery. Spine, 30, 1460-1465. https://doi.org/10.1097/01.brs.0000166532.58227.4f

[8] Lai, Q., Song, Q., Guo, R., Bi, H., Liu, X., Yu, X., Zhu, J., Dai, M. and Zhang, B. (2017) Risk Factors for Acute Surgical Site Infections after Lumbar Surgery: A Retrospective Study. Journal of Orthopedic Surgery and Research, 12, Article No. 116. https://doi.org/10.1186/s13018-017-0612-1

[9] Nasser, R., Kosty, J.A., Shah, S., Wang, J. and Cheng, J. (2018) Risk Factors and Prevention of Surgical Site Infections Following Spinal Procedures. Global Spine Journal, 8, 44S-48S. http://journals.sagepub.com/doi/10.1177/2192568218806275 https://doi.org/10.1177/2192568218806275 
[10] Hampshire, N. (2014) National Healthcare Safety Network (NHSN) Surgical Site Infection Surveillance (SSI). CDC. http://www.cdc.gov/nhsn/pdfs/pscmanual/9pscssicurrent.pdf

[11] Malhotra, A., Kalra, V.B., Wu, X., Grant, R., Bronen, R.A. and Abbed, K.M. (2015) Imaging of Lumbar Spinal Surgery Complications. Insights into Imaging, 6, 579-590. https://doi.org/10.1007/s13244-015-0435-8

[12] Van Goethem, J.W.M., Parizel, P.M. and Jinkins, J.R. (2002) Review Article: MRI of the Postoperative Lumbar Spine. Neuroradiology, 44, 723-739. https://doi.org/10.1007/s00234-002-0790-2

[13] Aljabi, Y., Manca, A., Ryan, J. and Elshawarby, A. (2019) Value of Procalcitonin as a Marker of Surgical Site Infection Following Spinal Surgery. Surgeon, 17, 97-101. https://doi.org/10.1016/j.surge.2018.05.006

[14] Iwata, E., Shigematsu, H., Koizumi, M., Nakajima, H., Okuda, A., Morimoto, Y., Masuda, K., Yamamoto, Y. and Tanaka, Y. (2016) Lymphocyte Count at 4 Days Postoperatively and CRP Level at 7 Days Postoperatively. Spine, 41, 1173-1178. https://doi.org/10.1097/BRS.0000000000001501

[15] Iwata, E., Shigematsu, H., Yamamoto, Y., Tanaka, M., Okuda, A., Morimoto, Y., Masuda, K., Nakajima, H., Koizumi, M. and Tanaka, Y. (2018) Lymphocyte Count at 4 Days Postoperatively. Spine, 43, E1096-E1101. https://doi.org/10.1097/BRS.0000000000002617

[16] Mun, J.H., Kim, D.H., Ryu, K.S., Park, C.K. and Kim, M.C. (2019) Diagnostic Value of Early Inflammatory Reaction in Postoperative Infection of the Lumbar Spine. Journal of Korean Neurosurgical Society, 38, 206-210.

[17] Mok, J.M., Pekmezci, M., Piper, S.L., Boyd, E., Berven, S.H., Burch, S., Deviren, V., Tay, B. and Hu, S.S. (2008) Use of C-Reactive Protein after Spinal Surgery: Comparison with Erythrocyte Sedimentation Rate as Predictor of Early Postoperative Infectious Complications. Spine, 33, 415-421. https://doi.org/10.1097/BRS.0b013e318163f9ee

[18] Wu, Y.L., Yo, C.H., Hsu, W.T., Qian, F., Wu, B.S., Dou, Q.L. and Lee, C.C. (2020) Accuracy of Heparin-Binding Protein in Diagnosing Sepsis: A Systematic Review and Meta-Analysis. Critical Care Medicine, 49, E80-E90. https://doi.org/10.1097/CCM.0000000000004738

[19] Linder, A., Åkesson, P., Brink, M., Studahl, M., Björck, L. and Christensson, B. (2011) Heparin-Binding Protein: A Diagnostic Marker of Acute Bacterial Meningitis. Critical Care Medicine, 39, 812-817. https://doi.org/10.1097/CCM.0b013e318206c396

[20] Linder, A., Soehnlein, O. and Kesson, P. (2010) Roles of Heparin-Binding Protein in Bacterial Infections. Journal of Innate Immunity, 2, 431-438.

https://doi.org/10.1159/000314853

[21] Mehta, A.I., Babu, R., Karikari, I.O., Grunch, B., Agarwal, V.J., Owens, T.R., Friedman, A.H., Bagley, C.A. and Gottfried, O.N. (2012) 2012 Young Investigator Award Winner: The Distribution of Body Mass as a Significant Risk Factor for Lumbar Spinal Fusion Postoperative Infections. Spine, 37, 1652-1656.

https://doi.org/10.1097/BRS.0b013e318241b186

[22] Zhang, L. and Li, E.N. (2018) Risk Factors for Surgical Site Infection Following Lumbar Spinal Surgery: A Meta-Analysis. Therapeutics and Clinical Risk Management, 14, 2161-2169. https://doi.org/10.2147/TCRM.S181477

[23] Haleem, A., Chiang, H.Y., Vodela, R., Behan, A., Pottinger, J.M., Smucker, J., Greenlee, J.D., Clark, C. and Herwaldt, L.A. (2016) Risk Factors for Surgical Site In- 
fections Following Adult Spine Operations. Infection Control and Hospital Epidemiology, 37, 1458-1467. https://doi.org/10.1017/ice.2016.193

[24] Klemencsics, I., Lazary, A., Szoverfi, Z., Bozsodi, A., Eltes, P. and Varga, P.P. (2016) Risk Factors for Surgical Site Infection in Elective Routine Degenerative Lumbar Surgeries. Spine Journal, 16, 1377-1383. https://doi.org/10.1016/j.spinee.2016.08.018

[25] Kobayashi, Y., Inose, H., Ushio, S., Yuasa, M., Hirai, T., Yoshii, T. and Okawa, A. (2020) Body Mass Index and Modified Glasgow Prognostic Score Are Useful Predictors of Surgical Site Infection after Spinal Instrumentation Surgery: A Consecutive Series. Spine, 45, E148-E154. https://doi.org/10.1097/BRS.0000000000003226

[26] Sang, C., Chen, X., Ren, H., Meng, Z., Jiang, J. and Qin, Y. (2020) Correlation between Lumbar Multifidus Fat Infiltration and Lumbar Postoperative Infection: A Retrospective Case-Control Study. BMC Surgery, 20, Article No. 35.

https://doi.org/10.1186/s12893-019-0655-9

[27] Katsevman, G.A., Daffner, S.D., Brandmeir, N.J., Emery, S.E., France, J.C. and Sedney, C.L. (2020) Complexities of Spine Surgery in Obese Patient Populations: A Narrative Review. The Spine Journal, 20, 501-511.

https://doi.org/10.1016/j.spinee.2019.12.011

[28] Olsen, M.A., Nepple, J.J., Riew, K.D., Lenke, L.G., Bridwell, K.H., Mayfield, J. and Fraser, V.J. (2008) Risk Factors for Surgical Site Infection Following Orthopedic Spinal Operations. Journal of Bone and Joint Surgery—Series A, 90, 62-69. https://doi.org/10.2106/JBJS.F.01515

[29] Hwang, J.U., Son, D.W., Kang, K.T., Lee, S.H., Lee, J.S., Song, G.S., Lee, S.W. and Sung, S.K. (2019) Importance of Hemoglobin A1c Levels for the Detection of Post-Surgical Infection Following Single-Level Lumbar Posterior Fusion in Patients with Diabetes. Korean Journal of Neurotrauma, 15, 150-158.

https://doi.org/10.13004/kjnt.2019.15.e36

[30] Peng, W., Liang, Y., Lu, T., Li, M., Li, D.S., Du, K.H. and Wu, J.H. (2019) Multivariate Analysis of Incision Infection after Posterior Lumbar Surgery in Diabetic Patients: A Single-Center Retrospective Analysis. Medicine, 98, e15935. https://doi.org/10.1097/MD.0000000000015935

[31] Kanafani, Z.A., Dakdouki, G.K., El-Dbouni, O., et al. (2006) Surgical Site Infections Following Spinal Surgery at a Tertiary Care Center in Lebanon: Incidence, Microbiology, and Risk Factors. Scandinavian Journal of Infectious Diseases, 38, 589-592. https://doi.org/10.1080/00365540600606440

[32] Sorensen, L.T. (2012) Wound Healing and Infection in Surgery. Annals of Surgery, 255, 1069-1079. https://doi.org/10.1097/SLA.0b013e31824f632d

[33] Pei, H., Zhang, L.J., Zeng, L.M. and Yu, F. (2014) Effect of Preoperative Smoking Intervention on Postoperative Complications of Total Hip Replacement. Chinese Journal of Evidence-Based Medicine, 14, 399-403.

[34] Kim, B.D., Hsu, W.K., De Oliveira, G.S., Saha, S. and Kim, J.Y.S. (2014) Operative Duration as an Independent Risk Factor for Postoperative Complications in Single-Level Lumbar Fusion: An Analysis of 4588 Surgical Cases. Spine, 39, 510-520. https://doi.org/10.1097/BRS.0000000000000163

[35] Meredith, D.S., Kepler, C.K., Huang, R.C., Brause, B.D. and Boachie-Adjei, O. (2012) Postoperative Infections of the Lumbar Spine: Presentation and Management. International Orthopedics, 36, 439-444. https://doi.org/10.1007/s00264-011-1427-z

[36] Louie, P.K., Haws, B.E., Khan, J.M., Markowitz, J., Movassaghi, K., Ferguson, J., Lopez, G.D., An, H.S. and Phillips, F.M. (2019) Comparison of Stand-Alone Lateral Lumbar Interbody Fusion versus Open Laminectomy and Posterolateral Instru- 
mented Fusion in the Treatment of Adjacent Segment Disease Following Previous Lumbar Fusion Surgery. Spine, 44, E1461-E1469. https://doi.org/10.1097/BRS.0000000000003191

[37] Mueller, K., Zhao, D., Johnson, O., Sandhu, F.A. and Voyadzis, J.M. (2019) The Difference in Surgical Site Infection Rates between Open and Minimally Invasive Spine Surgery for Degenerative Lumbar Pathology: A Retrospective Single Center Experience of 1442 Cases. Operative Neurosurgery, 16, 750-755. https://doi.org/10.1093/ons/opy221

[38] Parker, S.L., Adogwa, O., Witham, T.F., Aaronson, O.S., Cheng, J. and McGirt, M.J. (2011) Post-Operative Infection after Minimally Invasive versus Open Transforaminal Lumbar Interbody Fusion (TLIF): Literature Review and Cost Analysis. $\mathrm{Mi}$ nimally Invasive Neurosurgery, 54, 33-37. https://doi.org/10.1055/s-0030-1269904

[39] Hollern, D.A., Woods, B.I., Shah, N.V., Schroeder, G.D., Kepler, C.K., Kurd, M.F., David Kaye, I., Millhouse, P.W., Diebo, B.G., Paulino, C.B., Hilibrand, A.S., Vaccaro, A.R. and Radcliff, K.E. (2019) Risk Factors for Pseudarthrosis after Surgical Site Infection of the Spine. International Journal of Spine Surgery, 13, 507-514. https://doi.org/10.14444/6068

[40] Akinduro, O.O., Miller, B.A., Haussen, D.C., Pradilla, G. and Ahmad, F.U. (2015) Complications of Intraoperative Epidural Steroid Use in Lumbar Discectomy: A Systematic Review and Meta-Analysis. Neurosurgical Focus, 39, 1-7. https://doi.org/10.3171/2015.7.FOCUS15269

[41] Akins, P.T., Harris, J., Alvarez, J.L., Chen, Y., Paxton, E.W., Bernbeck, J. and Guppy, K.H. (2015) Risk Factors Associated with 30-Day Readmissions after Instrumented Spine Surgery in 14,939 Patients: 30-Day Readmissions after Instrumented Spine Surgery. Spine, 40, 1022-1032.

https://doi.org/10.1097/BRS.0000000000000916

[42] Yamamoto, Y., Shigematsu, H., Iwata, E., Nakajima, H., Tanaka, M., Okuda, A., Kawasaki, S., Suga, Y., Masuda, K. and Tanaka, Y. (2020) Hypoalbuminemia Increased the Length of Stay in the Treatment of Postoperative Acute Surgical Site Infection in Spinal Surgery. Spine, 45, E1564-E1571. https://doi.org/10.1097/BRS.0000000000003684

[43] Bohl, D.D., Shen, M.R., Mayo, B.C., Massel, D.H., Long, W.W., Modi, K.D., Basques, B.A. and Singh, K. (2016) Malnutrition Predicts Infectious and Wound Complications Following Posterior Lumbar Spinal Fusion. Spine, 41, 1693-1699. https://doi.org/10.1097/BRS.0000000000001591

[44] Phan, K., Ranson, W., White, S.J.W., Cheung, Z.B., Kim, J., Shin, J.I., Ukogu, C. Lee, N.J., Kothari, P. and Cho, S.K. (2019) Thirty-Day Perioperative Complications, Prolonged Length of Stay, and Readmission Following Elective Posterior Lumbar Fusion Associated with Poor Nutritional Status. Global Spine Journal, 9, 417-423. https://doi.org/10.1177/2192568218797089

[45] Rechtine, G.R., Bono, P.L., Cahill, D., Bolesta, M.J. and Chrin, A.M. (2001) Postoperative Wound Infection after Instrumentation of Thoracic and Lumbar Fractures. Journal of Orthopedic Trauma, 15, 566-569. https://doi.org/10.1097/00005131-200111000-00006

[46] d'Astorg, H., Fière, V., Dupasquier, M., Vieira, T.D. and Szadkowski, M. (2020) Enhanced Recovery after Surgery (ERAS) Protocol Reduces LOS without Additional Adverse Events in Spine Surgery. Orthopedics and Traumatology: Surgery and Research, 106, 1167-1173. https://doi.org/10.1016/j.otsr.2020.01.017

[47] Singla, A., Qureshi, R., Chen, D.Q., Nourbakhsh, A., Hassanzadeh, H., Shimer, A.L. 
and Shen, F.H. (2019) Risk of Surgical Site Infection and Mortality Following Lumbar Fusion Surgery in Patients with Chronic Steroid Usage and Chronic Methicillin-Resistant Staphylococcus aureus Infection. Spine, 44, E408-E413. https://doi.org/10.1097/BRS.0000000000002864

[48] Ranson, W.A., White, S.J.W., Cheung, Z.B., Mikhail, C., Ye, I., Kim, J.S. and Cho, S.K. (2018) The Effects of Chronic Preoperative Steroid Therapy on Perioperative Complications Following Elective Posterior Lumbar Fusion. Global Spine Journal, 8, 834-841. https://doi.org/10.1177/2192568218775960

[49] Tsubouchi, N., Fujibayashi, S., Otsuki, B., Izeki, M., Kimura, H., Ota, M., Sakamoto, T., Uchikoshi, A. and Matsuda, S. (2018) Risk Factors for Implant Removal after Spinal Surgical Site Infection. European Spine Journal, 27, 2481-2490. https://doi.org/10.1007/s00586-017-5294-1

[50] Yuan, W., Liu, X., Zhou, X., Pei, L. and Zhu, Y. (2018) Management of Early Deep Wound Infection after Thoracolumbar Instrumentation. Spine, 43, E1089-E1095. https://doi.org/10.1097/BRS.0000000000002615

[51] Watt, J.P. and Dunn, R.N. (2017) The Use of Vacuum Dressings for Dead Space Management in Deep Surgical Site Infections Allows Implant and Bone Graft Retention. Global Spine Journal, 7, 756-761. https://doi.org/10.1177/2192568217696694

[52] Quaile, A. (2012) Infections Associated with Spinal Implants. International Orthopaedics, 36, 451-456. https://doi.org/10.1007/s00264-011-1408-2

[53] Boody, B.S., Jenkins, T.J., Hashmi, S.Z., Hsu, W.K., Patel, A.A. and Savage, J.W. (2015) Surgical Site Infections in Spinal Surgery. Journal of Spinal Disorders and Techniques, 28, 352-362. https://doi.org/10.1097/BSD.0000000000000339

[54] Yang, S.C., Chiu, Y.C., Chen, H.S., Kao, Y.H., Jou, I.M. and Tu, Y.K. (2019) Percutaneous Endoscopic Debridement and Drainage for the Treatment of Instrumented Lumbar Spine Infection. Journal of Orthopedic Surgery, 27, 1-7. https://doi.org/10.1177/2309499019863356

[55] Hey, H.W.D., Thiam, D.W., Koh, Z.S.D., Thambiah, J.S., Kumar, N., Lau, L.L., Liu, K.P.G. and Wong, H.K. (2017) Is Intraoperative Local Vancomycin Powder the Answer to Surgical Site Infections in Spine Surgery? Spine, 42, E267-E274. https://doi.org/10.1097/BRS.0000000000001710

[56] Tomov, M., Mitsunaga, L., Durbin-Johnson, B., Nallur, D. and Roberto, R. (2015) Reducing Surgical Site Infection in Spinal Surgery with Betadine Irrigation and Intrawound Vancomycin Powder. Spine, 40, 491-499. https://doi.org/10.1097/BRS.0000000000000789

[57] Kobayashi, K., Imagama, S., Ando, K., Nakashima, H., Kato, F., Sato, K., Kanemura, T., Matsubara, Y., Yoshihara, H., Hirasawa, A., Deguchi, M., Shinjo, R., Sakai, Y., Inoue, H. and Ishiguro, N. (2020) Trends in Reoperation for Surgical Site Infection after Spinal Surgery with Instrumentation in a Multicenter Study. Spine, 45, 1459-1466. https://doi.org/10.1097/BRS.0000000000003545 


\section{Abbreviations}

SSI: Surgical Site Infection

BMI: Body Mass Index

HBP: Heparin-binding protein,

PCT: Procalcitonin Test

CRP: C-reactive protein

ESR: Erythrocyte Sedimentation Rate

MRI: Magnetic Resonance Imaging

WMD: Weighted Mean difference

DM: Diabetes Mellitus

ERAS: Enhance Recovering After Surgery

MIS-TLIF: Minimal Invasive Surgery-Transforaminal Lumbar Interbody Fusion, Endo-LIF: full-endoscopic translaminar lumbar interbody fusion

UBE: Unilateral bi-portal Endoscopic technique 